\title{
AKTIVITAS KAPAL PUKAT CINCIN SIBOLGA TAHUN 2002-2005 DAN LAJU TANGKAP PUKAT RAPAT DAN PUKAT JARANG PADA PERIODE BULAN JANUARI-JULI 2005 (PASCA TSUNAMI)
}

\author{
Tuti Hariati ${ }^{1)}$ dan Bambang Sadhotomo') \\ 1) Peneliti pada Balai Riset Perikanan Laut, Muara Baru-Jakarta \\ Teregristrasi I tanggal: 12 April 2006; Diterima setelah perbaikan tanggal: 13 Juli 2007; \\ Disetujui terbit tanggal: 6 Nopember 2007
}

\begin{abstract}
ABSTRAK
Sumber daya ikan pelagis di perairan barat Sumatera dimanfaatkan antara lain oleh armada pukat cincin di Sibolga, menggunakan 2 jenis pukat antara lain pukat rapat yang berukuran mata jaring 1 inci pada bagian kantung, adalah untuk menangkap ikan pelagis kecil, dan pukat jarang yang berukuran mata jaring 3 inci untuk menangkap ikan pelagis besar. Dalam 1 trip hanya dioperasikan 1 jenis pukat. Tujuan riset adalah untuk memperoleh informasi upaya penangkapan (jumlah trip) selama tahun 2002 sampai dengan 2005; serta hasil tangkapan, jumlah hari di laut dan laju tangkap pukat cincin Sibolga pada periode bulan Januari sampai dengan Juli 2005 (pasca Tsunami). Data hasil tangkapan dan jumlah hari di laut 13 kapal contoh dikumpulkan dari salah satu tangkahan, lalu di rise terhadap total jumlah trip untuk memperoleh dugaan hasil tangkapan kapal pukat cincin di seluruh Sibolga. Hasil riset menunjukkan, pada tahun 2004 di Sibolga terjadi penurunan jumlah trip kapal pukat cincin yang tajam dibandingkan pada tahun 2002 dan 2003. Pada tahun 2004 beberapa kapal pukat cincin Sibolga tidak dapat melaut karena belum memiliki surat perpanjangan izin beroperasi. Pada bulan Januari dan Pebruari 2005 penurunan aktivitas berlanjut karena ada kerusakan tangkahan dan armada akibat Tsunami dan gempa, sedangkan pada pertengahan tahun terjadi kenaikan jumlah trip dari kapal yang sudah memperoleh perpanjangan izin. Bulan September sampai dengan Desember tahun 2005 penurunan aktivitas terutama disebabkan oleh kelangkaan dan naik harga bahan bakar minyak sehingga biaya operasi semakin tinggi. Selama periode bulan Januari sampai dengan Juli 2005, meningkat laju tangkap pukat rapat dan pukat jarang diduga akibat dari turun jumlah hari di laut ke-2 jenis pukat tersebut. Jenis-jenis ikan yang tertangkap sesudah Tsunami sama dengan sebelum.
\end{abstract}

KATAKUNCI: aktivitas, kapal pukat sibolga, pasca tsunami

ABSTRACT: The activities of purse seiner of Sibolga during years 2002 until 2005, and the catch rate of both pukat rapat and pukat jarang during the period of January-July 2005 (after Tsunami disaster). By:Tuti Hariati and Bambang Sadhotomo

The pelagic resources from the waters of western Sumatera were exploited among other thing purse seiner fleet of Sibolga. Two kinds of seine were used; pukat rapat (1 inch mesh size in the bag part) to catch small pelagic fishes, and pukat jarang (3 inches mesh size) to catch some big pelagic fishes. During one trip only one kind of seine was used. The aim of this research was to get the information of the efforts (number of trip) during years 2002 until 2005, and the catch, days at sea, and catch rate of Sibolga's purse seiners in the periods of January until July 2005 (after Tsunami disaster). Catch by the species, number of trip, as well as days at sea data of the 13 unit of purse seiners of a private landing site were collected, then they were rised to the total number of trip in Sibolga, to estimate the total catch of the purse seiners in Sibolga. The result shows that during the year of 2004 the activities (trip) of the purse seiners decreased sharply, since several of purse seiners which had not got the recent document of permission could not go fishing. During January and February 2005, declining of the activities were continued since Tsunami and earth quake disaster had destroyed landing site and vessels. The rising of operational cost from September to December 2004 which were caused by the rareness of oil and rising of oil price had also decreased the number of active vessel. It was estimated that during the period of January until July 2005, the rise of catch rates of both pukat rapat and pukat jarang was caused by the decrease of days at sea. The species of fishes caught after Tsunami disaster were still the same with species of fishes caught before.

KEYWORDS: $\quad$ activity, Sibolga's purse seine, after Tsunami 


\section{PENDAHULUAN}

Perairan barat Sumatera merupakan daerah penangkapan yang produktif bagi ikan pelagis dan kelompok jenis ikan lain seperti demersal dan karang. Perairan di sepanjang pantai barat pulau Sumatera yang dibatasi oleh barisan kepulauan antara lain Pulau Simelue, Kepulauan Banyak; Pulau Nias, Pulau Pini dan Kepulauan Batu; serta Kepulauan Mentawai, Pulau Pagai sampai dengan Pulau Enggano merupakan daerah penangkapan sumber daya ikan pelagis kecil termasuk ikan teri (Hariati, 2005). Dari hasil penelitian dengan metode akustik, Wijopriono \& Priatna (2005) menemukan sebaran densitas ikan pelagis kecil dari lepas Pantai Lhok Nga (sebelah barat Banda Aceh) sampai dengan sebelah barat Pulau Nias 90 sampai dengan 100 ekor ikan per 1.000 m kubik pada kedalaman antara 0 dan $100 \mathrm{~m}$.

Armada pukat cincin Sibolga yang didominasi kapal berukuran 70 sampai dengan 100 GT melakukan operasi penangkapan di wilayah perairan Simelue dan Kepulauan Mentawai. Sebagai sasaran utama adalah jenis-jenis ikan pelagis kecil yang berkumpul di bawah rumpon, terutama ikan layang (Decapterus russelli dan D. macrosoma) dan ikan banyar (Rastrelliger kanagurta) yang ditangkap dengan pukat rapat (ukuran mata jaring 1 inci panjang jaring $700 \mathrm{~m}$ dan lebar 60 $\mathrm{m})$. Jika tidak ada ikan yang berkumpul, penangkapan beralih pada sasaran alternatif yaitu ikan pelagis besar terutama ikan cakalang (Katsuwonus pelamis), madidihang (Thunnus albacares), dan tongkol (Auxis thazard dan Euthynnus affinis) dengan menggunakan pukat jarang (ukuran mata jaring 3 sampai dengan 4 inci, panjang jaring $1.000 \mathrm{~m}$ dan lebar $100 \mathrm{~m}$ ), tanpa alat bantu, hanya dengan cara mengejar gerombolan ikan (Hariati, 2005).

Perairan yang merupakan daerah penangkapan ikan pelagis besar bagi pukat jarang Sibolga antara lain sebelah barat daya (lepas pantai) Nias di wilayah Sumatera Utara sampai dengan ke lepas Pantai Mentawai di wilayah Sumatera Barat. Perairan tersebut juga merupakan daerah penangkapan armada pancing tonda dari Padang. Pada bulan Desember 1993 di sekitar perairan tersebut ditemukan konsentrasi fosfat dan nitrat yang tinggi (Herlisman, 2003), diduga karena mendapat suplai air laut dari sisi pantai barat Sumatera, sehingga kelimpahan fitoplankton di perairan tersebut tinggi. Menurut Herlisman (2003) sirkulasi massa air dan penyebaran parameter fisika kimia dan biologi laut (plankton) di perairan Mentawai dan di sekitar diduga berdampak positif pada penyebaran dan kelimpahan ikan, terutama jenis yang dominan.
Menurut Hirata (2005) selama 40 tahun terakhir gempa di dasar perairan barat Sumatera sepanjang $1.300 \mathrm{~km}$ pada posisi antara $4^{\circ}$ dan $5^{\circ} \mathrm{LU}$, yang terjadi pada akhir bulan Desember 2004 merupakan gempa yang terbesar. Setelah Tsunami, masyarakat Sibolga yang tidak jauh dari Pulau Nias, sering merasakan terjadi gempa-gempa susulan, antara lain pada bulan September 2005. Meskipun demikian sampai dengan bulan tersebut kegiatan perikanan pukat cincin di Sibolga berlangsung. Sulistijo et al. (2005) menduga, dampak Tsunami tanggal 24 Desember 2004 sangat sedikit atau tidak berdampak terhadap komposisi hasil tangkapan ikan pelagis kecil.

Selama tahun 2003, dari pengoperasian pukat rapat menggunakan alat bantu yang terdiri atas rumpon dan cahaya lampu merkuri, 52,7\% dari total hasil tangkapan (25.706,7 ton) terdiri atas jenis-jenis ikan pelagis kecil. Hasil tangkapan pukat jarang pada tahun 2003 (28.812,9 ton), didominasi jenis-jenis ikan pelagis besar $(76,2 \%)$ (Hariati, 2005). Menurut Sadhotomo et al. (2005) perkembangan pola penangkapan armada pukat cincin di perairan barat Sumatera yang menyebabkan perubahan dalam struktur hasil tangkapan ini belum terdata oleh statistik perikanan. Selanjutnya, Sadhotomo et al. (2005) menyarankan dilakukan pengambilan contoh khusus untuk meningkatkan kualitas data statistik perikanan.

Tujuan penelitian ini adalah untuk memperoleh informasi tentang hasil tangkapan dan upaya serta laju tangkap perikanan pukat cincin Sibolga pada periode bulan Januari sampai dengan Juli 2005, setelah Tsunami. Menurut Sadhotomo et al. (2005), pengumpulan dan kompilasi hasil tangkapan pukat cincin Sibolga dari tiap-tiap kapal, khusus setelah Tsunami dapat merupakan perbandingan yang baik terhadap data tahun 2003 (Hariati, 2005) yang mewakili periode sebelum Tsunami.

\section{BAHAN DAN METODE}

Penelitian perikanan pelagis kecil dari perairan barat Sumatera paska Tsunami dilakukan di sentra perikanan pukat cincin Sibolga pada periode bulan Januari sampai dengan September 2005. Data jumlah kapal pukat cincin tahun 1985 sampai dengan 2005 dikutip dari Buku Statistik Dinas Perikanan Propinsi Sumatera Utara. Jumlah trip tiap bulan kapal pukat cincin di Sibolga tahun 2002 sampai dengan 2005 dikutip dari Kantor Administrasi Pelabuhan Sibolga. Hasil tangkapan 14 unit contoh kapal pukat cincin, jumlah trip pukat rapat (sasaran ikan pelagis kecil) 
dan pukat jarang (sasaran ikan pelagis besar) kapal contoh dari bulan Januari sampai dengan Juli 2005 diperoleh dari salah satu tangkahan. Data hasil tangkapan pukat cincin selama tahun 2004 tidak tersedia karena pada bulan Desember 2004 tangkahan terendam air pasang Tsunami. Jumlah hari di laut tiap trip diperoleh dari tanggal mendarat kapal contoh serta hasil wawancara di tangkahan.

Analisis dilakukan secara tabulasi dan grafis terhadap jumlah kapal pukat cincin tiap tahun selama tahun 1985 sampai dengan 2005 dan jumlah trip pukat cincin bulanan selama tahun 2002 sampai dengan 2005.

Jumlah trip dan hasil tangkapan tiap trip dari 14 unit kapal contoh selama bulan Januari sampai dengan Juli 2005 dipisahkan menurut jenis pukat rapat dan pukat jarang. Tiap-tiap kapal contoh mengoperasikan ke-2 jenis pukat tersebut, dalam tiap trip hanya mengoperasikan 1 jenis pukat. Jumlah trip pukat rapat dan trip pukat jarang di seluruh Sibolga diduga berdasarkan pada proporsi jumlah trip pukat rapat dan pukat jarang dari ke -14 kapal contoh terhadap jumlah trip kapal pukat cincin di Sibolga pada bulan Januari sampai dengan Juli 2005. Lama di laut tiap trip, lama di perjalanan dan jumlah hari di laut diperoleh dengan cara wawancara terhadap nakhoda dan pengurus tiap-tiap kapal contoh.

Hasil tangkapan pukat rapat dan pukat jarang di Sibolga pada bulan Januari sampai dengan Juli 2005 diduga dengan cara me-rise hasil tangkapan pukat rapat dan pukat jarang dengan proporsi jumlah trip pukat rapat dan pukat jarang dari kapal-kapal contoh, terhadap jumlah trip pukat rapat dan pukat jarang di Sibolga. Laju tangkap tiap bulan dihitung dari jumlah hasil tangkapan dibagi dengan jumlah hari di laut.

\section{HASIL DAN BAHASAN}

\section{Hasil}

\section{Jumlah kapal}

a. Jumlah kapal pukat cincin tahun 1985 sampai dengan 2005

Dari tahun 1985 sampai dengan 2003 jumlah kapal pukat cincin di Sibolga mengalami puncak pada tahun 2000 sampai dengan 2002 yang mencapai 204 unit (Hariati, 2005). Pada periode tahun 2003 sampai dengan 2005 jumlah kapal turun dari 203 unit menjadi 198 unit pada tahun 2004 dan 152 unit pada tahun 2005 (Gambar 1), karena sebagian kecil dari kapalkapal pukat cincin berpindah operasi di wilayah pengelolaan perikanan lain yaitu di Laut Flores dan Laut Banda (dari Dinas Perikanan dan Kelautan terkait). Sebagian besar lain akibat kelangkaan dan kenaikan harga bahan bakar minyak pada tahun 2005, banyak di antara kapal pukat cincin yang tidak mampu beroperasi karena biaya operasi meningkat. Mulai tahun 2004 banyak dilakukan patroli di laut oleh Direktorat Pengawasan Sumber Daya Kelautan dan Perikanan dan Tentara Nasional Indonesia Angkatan

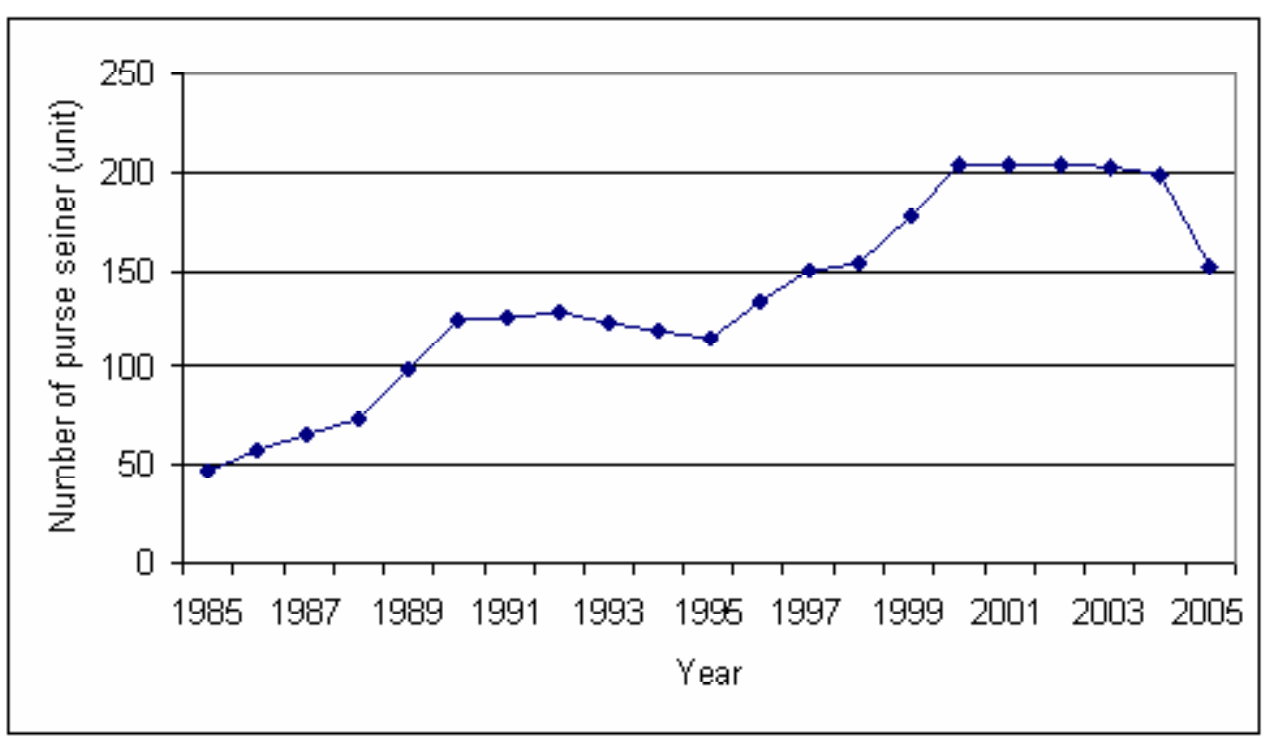

Gambar 1. Perkembangan jumlah unit kapal pukat cincin Sibolga.

Figure 1. Development of number of purse seiner of Sibolga. Source: Extention fisheries for South Sumatera Fisheries 
b. Jumlah trip tiap bulan

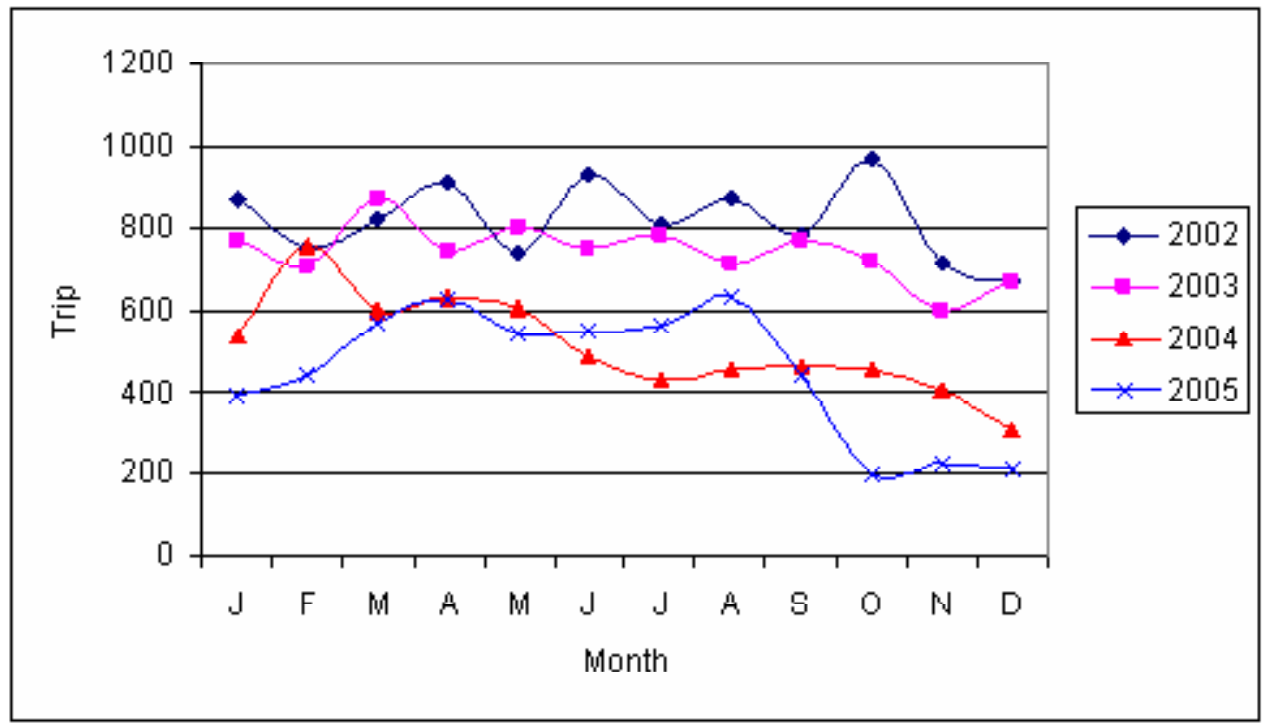

Gambar 2. Fluktuasi jumlah trip bulanan kapal pukat cincin Sibolga pada tahun 2002 sampai dengan 2005.

Figure 2. Monthly fluctuation of purse seiner number of trip in Sibolga 2002 - 2005.

Laut yang tidak mengizinkan kapal-kapal yang belum memperpanjang atau yang belum selesai perpanjangan izin.

Jumlah trip kapal pukat cincin Sibolga (Gambar 2) adalah gabungan jumlah trip pukat rapat (menangkap ikan pelagis kecil) dan pukat jarang (menangkap ikan pelagis besar), karena ke-2 jenis pukat tersebut dioperasikan oleh kapal yang sama pada trip yang berbeda. Ada 3 puncak jumlah trip pada tahun 2002 yaitu bulan April, Juni, dan Oktober. Pada tahun 2003, bulan Maret dan September juga merupakan puncak trip pukat rapat, sedangkan bulan Januari dan Oktober adalah puncak dari jumlah trip pukat jarang (Hariati, 2005). Jumlah trip pukat cincin Sibolga tiap bulan pada tahun 2002 dan 2003 menggambarkan aktivitas penangkapan pada kondisi normal.

Pada tahun 2004 dan 2005 terjadi penurunan aktivitas kapal pukat cincin. Hampir setiap bulan pada tahun 2004 (kecuali bulan Pebruari) jumlah trip turun secara nyata dari tahun 2003 (Gambar 2), karena banyak kapal-kapal pukat cincin yang belum memperoleh perpanjangan surat izin, sehingga tidak diizinkan untuk beroperasi. Pada tahun 2005 setelah terjadi Tsunami, sering terjadi gempa-gempa susulan sehingga jumlah trip (aktivitas) pada bulan Januari dan Pebruari 2005 menjadi rendah (Gambar 2). Dari bulan Maret sampai dengan September 2005 jumlah trip cenderung naik, karena sebagian dari kapal-kapal yang sudah memperoleh perpanjangan izin, beroperasi kembali. Turun jumlah trip secara tajam dari bulan Oktober sampai dengan Desember 2005 adalah dampak kelangkaan bahan bakar minyak yang disusul oleh kenaikan harga bahan bakar minyak untuk industri 3 kali lipat.

\section{c. Jumlah hari di laut pukat rapat dan pukat jarang}

Seperti pada tahun 2003, lama di laut tiap trip kapal pukat cincin Sibolga pada tahun 2005 baik menggunakan pukat rapat di daerah penangkapan di perairan Aceh Selatan atau perairan Tapanuli Selatan, maupun dengan pukat jarang di perairan lepas Pantai Mentawai 7 hari (sesuai dengan perbekalan yang diberi oleh tiap-tiap perusahaan) dengan lama di perjalanan pulang sampai dengan pergi 2 hari, sehingga jumlah hari di laut untuk beroperasi 5 hari, dengan 2 kali tawur pada tiap-tiap malam.

Selama periode bulan Januari Juli 2005, jumlah hari di laut pukat rapat tiap-tiap bulan turun dibandingkan dengan periode bulan Januari sampai dengan Juli 2003 (Tabel 1), karena kendala-kendala yang dihadapi nelayan baik gempa susulan maupun belum keluar izin penangkapan yang baru. Jumlah hari di laut pukat jarang tiap bulan juga turun, kecuali pada bulan Maret 2005 di mana kesempatan memperoleh gerombolan ikan pelagis besar lebih banyak daripada memperoleh gerombolan ikan pelagis kecil (Tabel 1, Gambar 3).

Selain pada bulan Maret 2005, jumlah hari di laut pukat rapat tiap bulan pada tahun 2005 lebih tinggi dari jumlah hari di laut pukat jarang (Gambar 3), 
Tabel 1. Jumlah hari di laut pukat rapat dan pukat jarang kapal pukat cincin Sibolga pada periode bulan Januari sampai dengan Juli tahun 2003 dan 2005

Table 1. Number of days at sea of both pukat rapat and pukat jarang Sibolga's purse seiner in the period of January to July years 2003 and 2005

\begin{tabular}{lcccccc}
\hline \multirow{2}{*}{ Bulan/Month } & \multicolumn{7}{c}{ Hari di laut/Day at sea (day) } \\
\cline { 2 - 7 } & \multicolumn{7}{c}{ Pukat rapat } & \multicolumn{3}{c}{ Pukat jarang } \\
\cline { 2 - 7 } & $\mathbf{2 0 0 3}$ & $\mathbf{2 0 0 5}$ & Trend & $\mathbf{2 0 0 3}$ & $\mathbf{2 0 0 5}$ & Trend \\
\hline Januari/January & 2.379 & 1.568 & Turun/Decrease & 1.476 & 392 & Turun/Decrease \\
Pebruari/February & 2.242 & 1.551 & Turun/Decrease & 1.293 & 665 & Turun/Decrease \\
Maret/March & 3.346 & 1.264 & Turun/Decrease & 1.004 & 1.581 & Naik/Increase \\
April/April & 2.612 & 2.434 & Turun/Decrease & 1.108 & 696 & Turun/Decrease \\
Mei/May & 2.982 & 2.180 & Turun/Decrease & 1.023 & 545 & Turun/Decrease \\
Juni/June & 2.381 & 1.827 & Turun/Decrease & 1.374 & 913 & Turun/Decrease \\
Juli/July & 2.822 & 1.530 & Turun/Decrease & 1.108 & 1.275 & Turun/Decrease \\
\hline Total & $\mathbf{1 8 . 7 6 4}$ & $\mathbf{1 2 . 3 5 4}$ & Turun/Decrease & $\mathbf{8 . 3 8 6}$ & $\mathbf{6 . 0 6 6}$ & Turun/Decrease \\
\hline
\end{tabular}

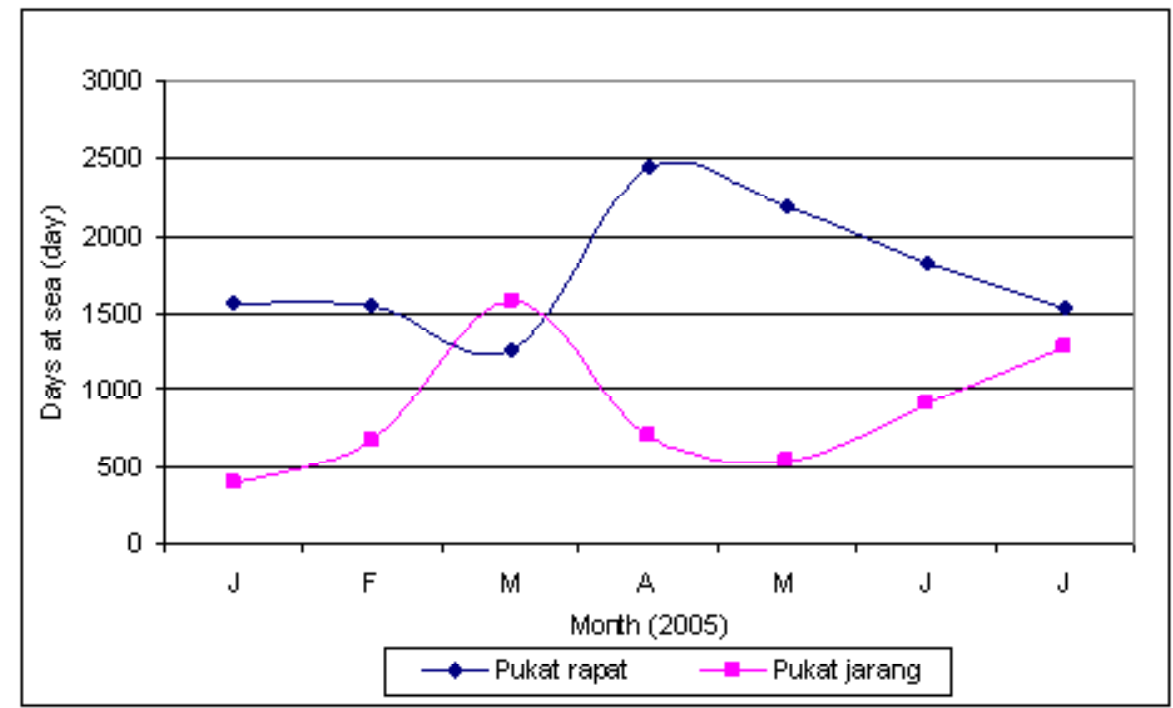

Gambar 3. Jumlah hari di laut pukat rapat dan pukat jarang armada pukat cincin Sibolga pada bulan Januari sampai dengan Juli 2005.

Figure 3. Day at sea of both pukat cincin rapat and pukat cincin jarang of Sibolga's purse seine fleet from January to July 2005.

karena tujuan utama pengoperasian pukat cincin Sibolga adalah menangkap ikan pelagis kecil, sedangkan menangkap ikan pelagis besar hanya dilakukan jika gerombolan ikan tidak banyak ditemukan di bawah rumpon.

Pada bulan Maret 2005 di mana peluang menemukan gerombolan ikan pelagis kecil sedikit dibandingkan dengan gerombolan ikan pelagis besar, jumlah hari di laut pukat rapat lebih rendah daripada pukat jarang. Jumlah hari di laut tertinggi untuk pukat rapat terjadi pada bulan April, sedangkan untuk pukat jarang pada bulan Maret (Gambar 3).

\section{Hasil Tangkapan Pukat Cincin Sibolga \\ Pukat rapat}

Jenis-jenis ikan hasil tangkapan pukat rapat pada periode bulan Januari sampai dengan Juli 2005 (Tabel
2), khususnya ikan pelagis kecil tetap sama seperti pada periode pra Tsunami, terdiri atas ikan layang (Decapterus russelli dan D. macrosoma), layang biru (D. macarellus), bentong (Selar crumenophthalmus), selar-selaran terutama selar hijau (Atule mate), dan selar kuning (Selaroides leptolepis), banyar (Rastrelliger kanagurta), kembung ( $R$. brachyosoma), siro (Ambligaster sirm), tembang (Sardinella gibbosa), japuh (Dussumieria acuta), dan tetengkek (Megalaspis cordyla) mencapai 65,3\% dari total hasil tangkapan; ikan tongkol (Auxis sp. dan Eutynnus sp.) $15,3 \%$, sejenis ikan pelagis besar yang tertangkap pukat rapat dan jenis-jenis ikan lain $(19,4 \%)$ terdiri atas tenggiri, sotong, cumi-cumi, alu-alu, layur, tuna, anak-anak ikan Carangidae, dan ikan demersal. Sulistijo et al. (2005) pada bulan Juli sampai dengan Agustus 2005 menemukan komposisi jenis ikan pelagis kecil yang sama dengan pada periode sebelum Tsunami. 
Jumlah hasil tangkapan beberapa jenis ikan pelagis kecil pada tahun 2005 meningkat dari tahun 2003 (Tabel 2) seperti layang biru, banyar, siro, dan tetengkek, sedangkan hasil tangkapan ikan layang, selar hijau, bentong, kembung, tembang, dan japuh

Tabel 2.

Hasil tangkapan pukat rapat Sibolga pada bulan Januari sampai dengan Juli tahun 2003 dan 2005

Table 2. Catch of pukat rapat of January to July period both 2003 - 2005 turun. Hasil tangkapan ikan tongkol yang pada tahun 2003 dominan, pada tahun 2005 cenderung turun.

Hasil tangkapan total pukat rapat pada bulan Januari sampai dengan Juli 2005 meningkat sekitar 7,6\% dari tahun 2003 (Tabel 2). Mengingat bahwa jumlah upaya (hari di laut) pada tahun 2005 turun

\begin{tabular}{|c|c|c|c|c|}
\hline \multirow[t]{2}{*}{ No. } & \multirow[t]{2}{*}{$\begin{array}{l}\text { Spesies dan nama Indonesia/ } \\
\text { Species and Indonesian name }\end{array}$} & \multicolumn{2}{|c|}{$\begin{array}{c}\text { Hasil tangkapan/ } \\
\text { Catch (ton) } \\
\text { January-July }\end{array}$} & \multirow[t]{2}{*}{ Trend/Trend } \\
\hline & & 2003 & 2005 & \\
\hline 1. & Decapterus russelli \& D. macrosoma (Layang) & $1.137, .2$ & 744,7 & Turun/Decrease \\
\hline 2. & D. macarellus (Layang biru) & 621,7 & $2.386,9$ & Naik/Increase \\
\hline 3. & Selar crumenophthalmus (Bentong) & $2.358,8$ & $1.982,0$ & Turun/Decrease \\
\hline 4. & Atule mate (Selar hijau) & 583,0 & 83,8 & Turun/Decrease \\
\hline 5. & Selaroides leptolepis (Selar kuning) & 0,0 & 23,0 & Naik/Increase \\
\hline 6. & Rastrelliger kanagurta (Banyar) & 646,2 & $2.101,3$ & Naik/Increase \\
\hline 7. & R. brachyosoma (Kembung) & 152,3 & 31,4 & Turun/Decrease \\
\hline 8. & Ambligaster sirm (Siro) & 383,6 & 658,2 & Naik/Increase \\
\hline 9. & Sardinella gibbosa (Tembang) & 628,0 & 207,5 & Turun/Decrease \\
\hline 10. & Dussumieria acuta (Japuh) & 152,9 & 15,0 & Turun/Decrease \\
\hline 11. & Megalaspis cordyla (Tetengkek) & 369,5 & 964,7 & Naik/Increase \\
\hline 12. & Auxis sp. \& Eutynnus sp. (Tongkol) & $2.889,4$ & $2.153,7$ & Turun/Decrease \\
\hline \multirow[t]{2}{*}{13.} & Lainnya & $3.527,1$ & $2.741,0$ & Turun/Decrease \\
\hline & Total & $13.449,7$ & $14.093,1$ & Naik/Increase \\
\hline
\end{tabular}

dibandingkan dengan tahun 2003, diduga pada tahun 2003 sumber daya ikan pelagis kecil di daerah penangkapan pukat cincin perairan barat Sumatera sudah mengalami tekanan penangkapan. Pada periode tahun 2005 terjadi pergeseran puncak hasil tangkapan pukat rapat dari bulan Maret (tahun 2003) ke bulan April dan Mei 2005 (Gambar 4), pada musim yang sama yaitu peralihan 1 .

Tinggi hasil tangkapan pada bulan April dan Mei 2005 diduga terkait dengan tinggi jumlah hari di laut pada ke-2 bulan tersebut (Gambar 3). Hasil tangkapan
5 jenis ikan pelagis yang dominan tiap bulan pada periode bulan Januari sampai dengan Juli 2003 dan bulan Januari sampai dengan Juli 2005.

Dari komposisi hasil tangkapan pukat cincin rapat pada tahun 2003 (Tabel 2), diperoleh 5 jenis ikan pelagis dominan yang terdiri atas jenis ikan pelagis besar yaitu ikan tongkol (Auxis sp. dan Eutynnus sp.) dan 4 jenis ikan pelagis kecil yaitu ikan bentong (Selar crumenophthalmus), layang (Decapterus russelli dan D. macrosoma), layang biru (D. macarellus), dan ikan banyar (Rastrelliger kanagurta).

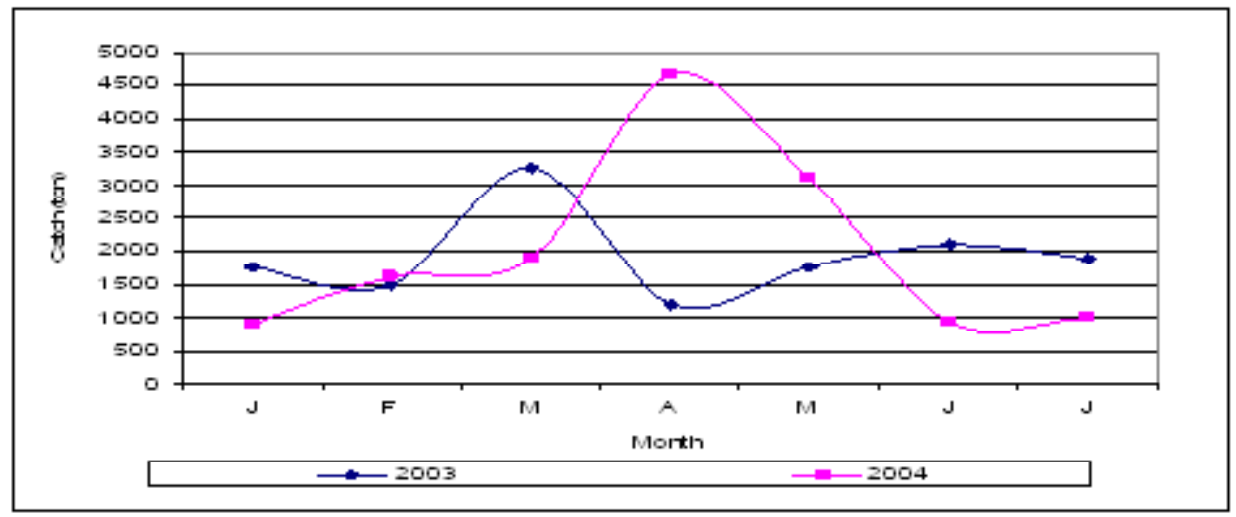

Gambar 4. Total hasil tangkapan pukat rapat armada pukat cincin Sibolga bulan Januari sampai dengan Juli tahun 2003 dan 2005.

Figure 4. Total catch of pukat rapat of Sibolga's purse seiner's fleet at a period of Januari to July 2003 and 2005. 


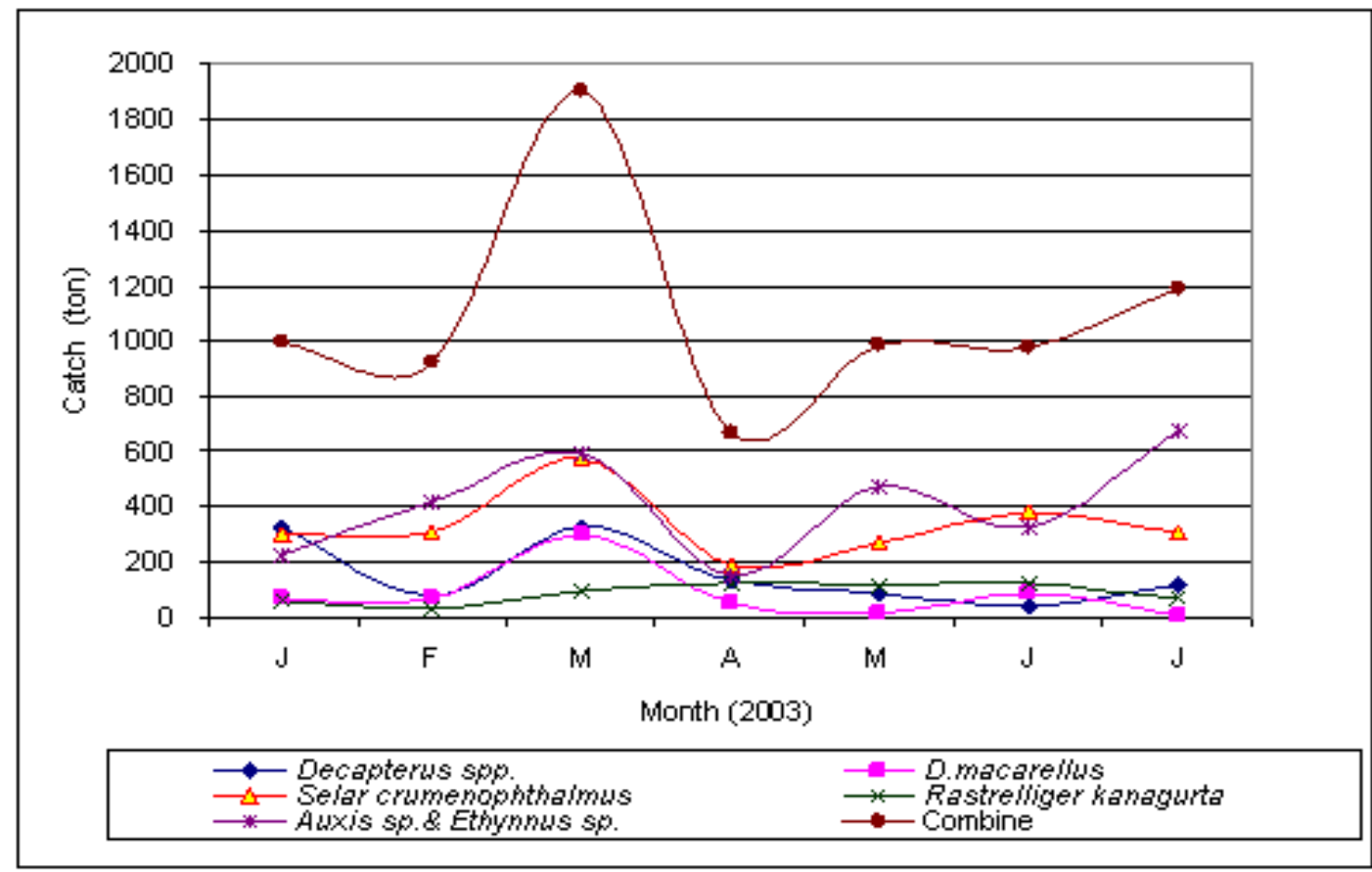

Gambar 4a. Hasil tangkapan 5 jenis ikan pelagis dominan oleh pukat cincin rapat Sibolga dari bulan Januari sampai dengan Juli 2003.

Figure 4a. Catch of the 5 dominant pelagic fishes by pukat rapat of Sibolga purse seiner' fleet from January to July 2003.

Pada bulan Maret 2003 ke-5 jenis ikan pelagis dominan tersebut mencapai hasil tangkapan tertinggi (Gambar 4a). Bulan Maret (musim peralihan 1) diketahui sebagai salah satu puncak hasil tangkapan pukat rapat selain bulan Oktober 2003 (musim peralihan 2, Hariati, 2005), didukung juga dengan jumlah hari di laut yang tinggi (Tabel 1). Pada tiap bulan, hasil tangkapan ikan tongkol (Auxis sp. dan Eutynnus affinis sp.) dan bentong (Selar crumenophthalmus) selalu tinggi kecuali pada bulan April; disusul dengan hasil tangkapan ikan layang (Decapterus russelli dan D. macrosoma), layang biru (D. macarellus), dan ikan banyar (Gambar 4a).

Dari Januari sampai dengan Juli 2005 hasil tangkapan ke-5 jenis ikan pelagis yang dominan berfluktuasi sangat menyolok, dari 0 ton (tidak ada) sampai dengan 600 ton tiap bulan sampai dengan $>1.200$ ton tiap bulan (Gambar 4b), terutama ikan layang biru (D. macarellus), tongkol (Auxis sp. dan Eutynnus affinis sp.) dan banyar (Rastrelliger kanagurta). Berbeda dengan tahun 2003, pada tahun 2005 secara temporal tiap jenis ikan hanya dominan pada beberapa bulan dengan jumlah hasil tangkapan yang jauh lebih tinggi dari tahun 2003, pada bulan berikut jumlah tersebut turun drastis.

Hasil tangkapan ikan tongkol (Auxis sp. dan Euthynnus sp.) dan layang (Decapterus russelli dan
D. macrosoma) dari bulan Januari sampai dengan Maret 2005 (beberapa saat setelah Tsunami), sangat rendah dibandingkan dengan periode tahun 2003, sedangkan hasil tangkapan ikan bentong (Selar crumenophthalmus) pada bulan Pebruari turun sampai dengan Maret 2005. Menurut nelayan pada ke-3 bulan tersebut, ikan yang berkumpul di bawah rumpon sulit ditemukan. Layang biru (D. macarellus) pada bulan Januari dan Maret 2005 bahkan tidak ada di dalam hasil tangkapan; yang ada hanya ikan bentong (dominan) dan ikan banyar dalam jumlah kecil.

Pada bulan Januari 2005 diperoleh hasil tangkapan ikan dominan yang paling rendah. Pada bulan Maret dan April 2005 hasil tangkapan ikan banyar naik sehingga mendominasi hasil tangkapan pukat rapat, sedangkan pada bulan Mei sampai dengan Juni 2005 kembali turun. Pada bulan Pebruari, April, dan Mei 2005, gerombolan ikan layang biru (D. macarellus) banyak dijumpai di luar rumpon dengan hasil yang lebih tinggi dari periode Januari sampai dengan Juli tahun 2003, pada bulan Juni dan Juli 2005 turun drastis (Gambar 4b).

Hasil tangkapan ikan layang meningkat pada bulan April (Gambar 4b) kemudian turun lagi pada bulan Mei sampai dengan Juli. Pada bulan April dan Mei hasil tangkapan ikan tongkol terus meningkat, 


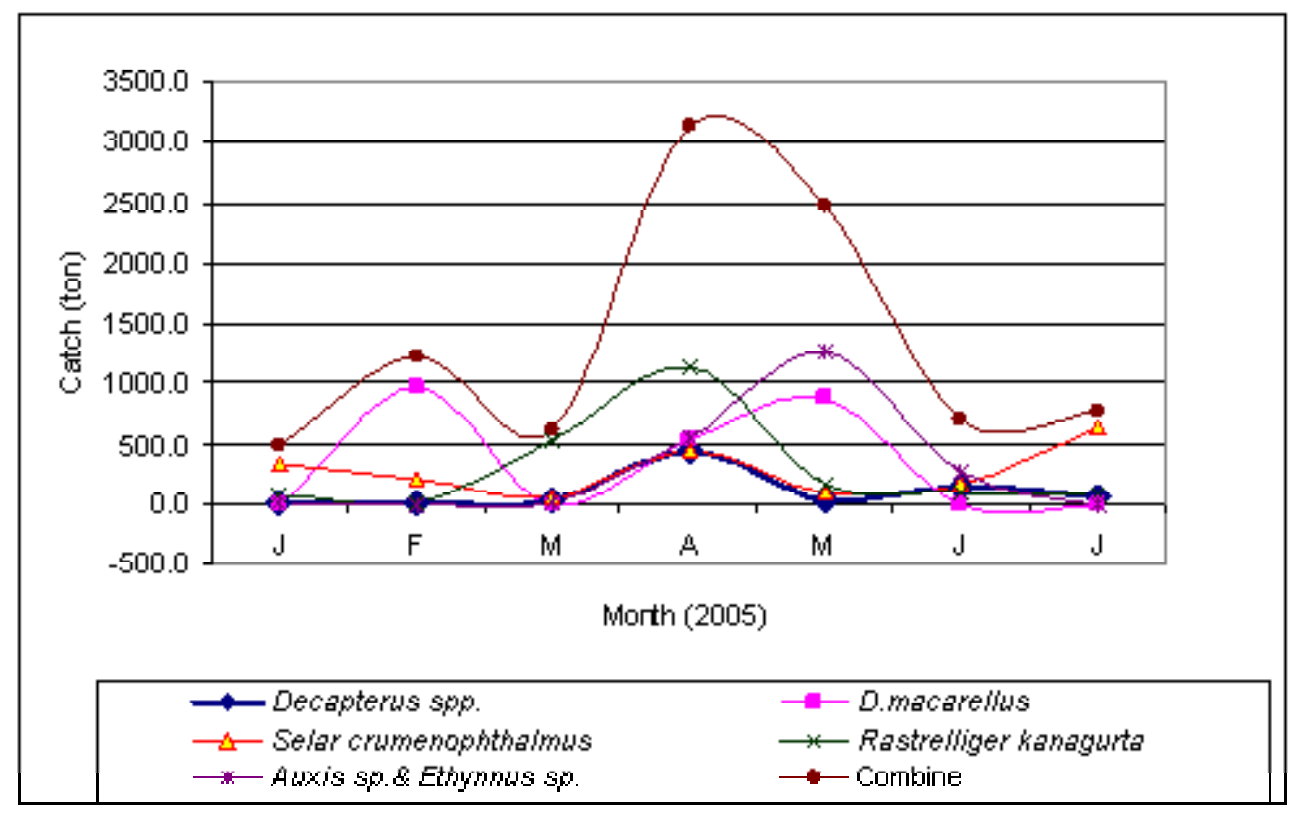

Gambar 4b. Hasil tangkapan 5 jenis ikan pelagis yang dominan oleh pukat rapat dari armada pukat cincin Sibolga dari bulan Januari sampai dengan Juli 2005.

Figure $4 b$. Catch of the 5 dominant pelagic fishes by pukat rapat of Sibolga purse seiner's fleet from January to July 2005.

sedangkan bentong (Selar crumenophthalmus) turun sampai dengan bulan Juni. Dari bulan Juni sampai dengan Juli 2005 hasil tangkapan ke-4 jenis ikan dominan turun, kecuali ikan bentong pada bulan Juli naik. Penurunan hasil tangkapan tersebut diduga karena ada pengaruh musim.

Seperti total hasil tangkapan pukat rapat (Gambar 4), pada bulan April 2005 ke-5 jenis ikan dominan dalam pukat rapat mencapai maksimum, juga pada bulan Mei jumlah hasil tangkapan relatif tinggi oleh peningkatan hasil tangkapan layang biru dan tongkol (Gambar 4b), karena pada bulan April dan Mei 2005 jumlah hari di laut pukat rapat cukup tinggi.

\section{Pukat jarang}

Jenis-jenis ikan hasil tangkapan pukat jarang pada periode bulan Januari sampai dengan Juli 2005 sama dengan pada tahun 2003 yang didominasi oleh ikan pelagis besar yaitu ikan cakalang (Katsuwonus pelamis), madidihang (Thunnus albacares), dan tongkol (Auxis thazard dan Eutynnus sp.), juga jenisjenis ikan lain (pelagis kecil, karang, dan demersal).

Hasil tangkapan ke-3 jenis ikan pelagis besar dan ikan lain-lain turun (Tabel 3). Hasil tangkapan total pukat jarang pada tahun 2005 juga turun dari tahun 2003 diduga karena jumlah upaya yang menurun dibandingkan dengan tahun 2003.

Tabel 3. Hasil tangkapan pukat jarang Sibolga pada periode bulan Januari sampai dengan Juli 2003 dan 2005

Table 3. $\quad$ Catch of pukat jarang at the period of January to July, in 2003 and 2005

\begin{tabular}{|c|c|c|c|c|}
\hline \multirow[t]{2}{*}{ No. } & \multirow[t]{2}{*}{$\begin{array}{l}\text { Spesies dan nama Indonesia/ } \\
\text { Species and Indonesian name }\end{array}$} & \multicolumn{2}{|c|}{$\begin{array}{c}\text { Hasil tangkapan/ } \\
\text { Catch (kg) } \\
\text { January-July } \\
\text { Tahun/Years }\end{array}$} & \multirow[t]{2}{*}{$\begin{array}{l}\text { Keterangan/ } \\
\text { Remark }\end{array}$} \\
\hline & & 2003 & 2005 & \\
\hline 1. & Katsuwonus pelamis(cakalang) & $9.362,0$ & $8.920,3$ & Turun/Decrease \\
\hline 2. & Thunnus albacares (tuna) & $2.147,3$ & $1.635,9$ & Turun/Decrease \\
\hline 3. & Auxis sp. dan Eutynnus sp. (tongkol) & 794,4 & 484,1 & Turun/Decrease \\
\hline \multirow[t]{2}{*}{4.} & Others(lain-lain) & $5.661,1$ & $1.863,3$ & Turun/Decrease \\
\hline & Total & $17.964,7$ & $12.903,6$ & Turun/Decrease \\
\hline
\end{tabular}




\section{Laju tangkap}

\section{Pukat rapat}

Nilai-nilai laju tangkap beberapa jenis ikan pelagis kecil yaitu ikan layang (Decapterus russelli dan $D$. macrosoma), siro (Ambligaster sirm), dan tongkol (Auxis sp. dan Eutynnus sp.-ikan pelagis besar) pada bulan Januari sampai dengan Juli 2005 cenderung tetap dibandingkan dengan pada tahun 2003 (Tabel 4). Laju tangkap jenis-jenis ikan pelagis kecil lain terutama layang biru, bentong, banyar, tembang selar kuning, dan tetengkek pada tahun 2005 mengalami kenaikan (Tabel 4). Hanya laju tangkap beberapa jenis ikan pelagis kecil yang turun yaitu selar hijau, kembung, dan japuh; ke-3 adalah spesies yang hidup terutama di perairan pantai. Secara total, laju tangkap pukat rapat mengalami kenaikan (Tabel 4 ) yang diduga karena turun jumlah upaya (Tabel 1).

Tabel 4. Laju tangkap jenis-jenis ikan dengan pukat rapat Sibolga pada bulan Januari sampai Juli tahun 2003 dan 2005

Table 4. Catch rate of many fishes by pukat rapat of Sibolga at the period of January to July, years 2003 and 2005

\begin{tabular}{|c|c|c|c|c|}
\hline \multirow[t]{2}{*}{ No. } & \multirow[t]{2}{*}{$\begin{array}{l}\text { Spesies dan nama Indonesia/ } \\
\text { Species and Indonesian name }\end{array}$} & \multicolumn{2}{|c|}{$\begin{array}{c}\text { Laju tangkap/ } \\
\text { Catch rate (kg/day) } \\
\text { January-July }\end{array}$} & \multirow[t]{2}{*}{ Trend } \\
\hline & & 2003 & 2005 & \\
\hline 1. & Decapterus russelli dan $D$. macrosoma (layang) & 56,6 & 51,3 & Tetap/Constant \\
\hline 2. & D. macarellus (layang biru) & 30,0 & 178,3 & Naik/Increase \\
\hline 3. & Selar crumenophthalmus (bentong) & 118,6 & 163,5 & Naik/Increase \\
\hline 4. & Atule mate (selar hijau) & 26,9 & 6,3 & Turun/Decrease \\
\hline 5. & Selaroides leptolepis (selar kuning) & 0,0 & 2,1 & Naik/Increase \\
\hline 6. & Rastrelliger kanagurta (banyar) & 32,5 & 161,0 & Naik/Increase \\
\hline 7. & R. brachyosoma (kembung) & 7,8 & 2,9 & Turun/Decrease \\
\hline 8. & Ambligaster sirm (siro) & 18,8 & 17,8 & Tetap/Constant \\
\hline 9. & Sardinella gibbosa (tembang) & 31,1 & 43,6 & Naik/Increase \\
\hline 10. & Dussumieria acuta (japuh) & 7,2 & 1,2 & Turun/Decrease \\
\hline 11. & Megalaspis cordyla (tetengkek) & 18,6 & 71,9 & Naik/Increase \\
\hline 12. & Auxis sp. dan Eutynnus sp. (tongkol) & 143,6 & 142,5 & Tetap/Constant \\
\hline \multirow[t]{2}{*}{13.} & Lain-lain & 180,9 & 244,4 & Naik/Increase \\
\hline & Total & 672,6 & $1.086,9$ & Naik/Increase \\
\hline
\end{tabular}

Laju tangkap 5 jenis ikan pelagis dominan yang tertangkap pukat rapat

Pada bulan Januari sampai dengan Juli 2003, gabungan laju tangkap ke-5 jenis ikan pelagis yang dominan mencapai nilai tertinggi pada bulan Maret 2003 dan terendah pada bulan April (Gambar 5a). Fluktuasi laju tangkap tiap jenis ikan yang dominan pada periode tahun 2003 ini serupa dengan fluktuasi hasil tangkapan, dengan ikan tongkol dan bentong hampir tiap bulan mencapai laju tangkap tertinggi, disusul oleh ikan layang, layang biru, dan banyar (Gambar 5a). Laju tangkap gabungan yang tertinggi berlangsung pada bulan Maret 2003, ketika hasil tangkapan gabungan mencapai jumlah tertinggi; dan terendah pada bulan April 2003 (Gambar 5a).

Pada tahun 2005, laju tangkap tiap bulan ke- 5 jenis ikan pelagis dominan tersebut sangat berfluktuasi
(Gambar 5b) sehingga penyebaran secara temporal kurang merata, mirip gambaran fluktuasi hasil tangkapan pada periode Januari sampai dengan Juli 2005 (Gambar 4b) di mana gabungan laju tangkap mencapai yang tertinggi pada bulan April dan Mei 2005 ketika hasil tangkapan pukat rapat tinggi dan jumlah hari di laut yang tinggi. Laju tangkap yang terendah pada bulan Januari 2005 (Gambar 5b).

Laju tangkap 2 jenis ikan pelagis besar yaitu ikan cakalang dan tuna, pada periode bulan Januari sampai dengan Juli 2005 naik dibandingkan dengan laju tangkap masing-masing pada periode yang sama tahun 2003, sebaliknya laju tangkap ikan tongkol dan ikan lain-lain turun (Tabel 5). Secara total, laju tangkap pukat jarang pada tahun 2005 naik dari tahun 2003, karena selain jumlah upaya pada tahun 2005 turun, ikan cakalang dan tuna mendominasi hasil tangkapan pukat jarang. 


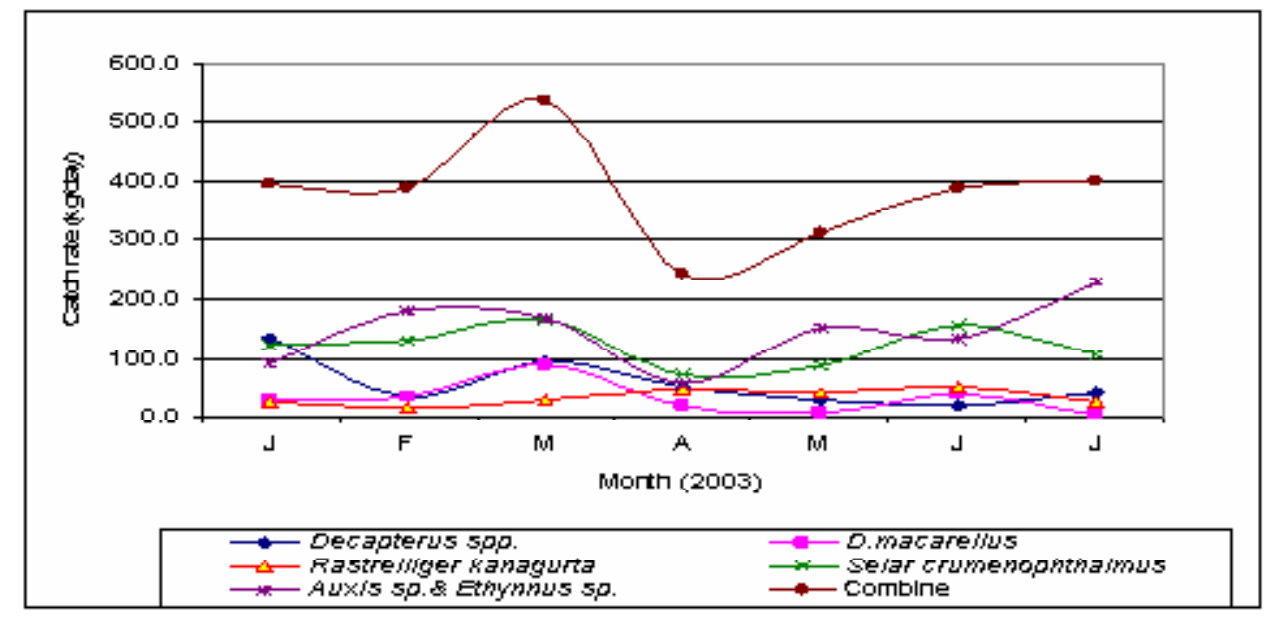

Gambar 5a. Laju tangkap 5 jenis ikan pelagis dominan oleh pukat cincin rapat Sibolga dari bulan Januari sampai dengan Juli 2003.

Figure 5a. Catch rate of the 5 dominant pelagic fishes by pukat rapat of Sibolga purse seiner' fleet from January to July 2003.

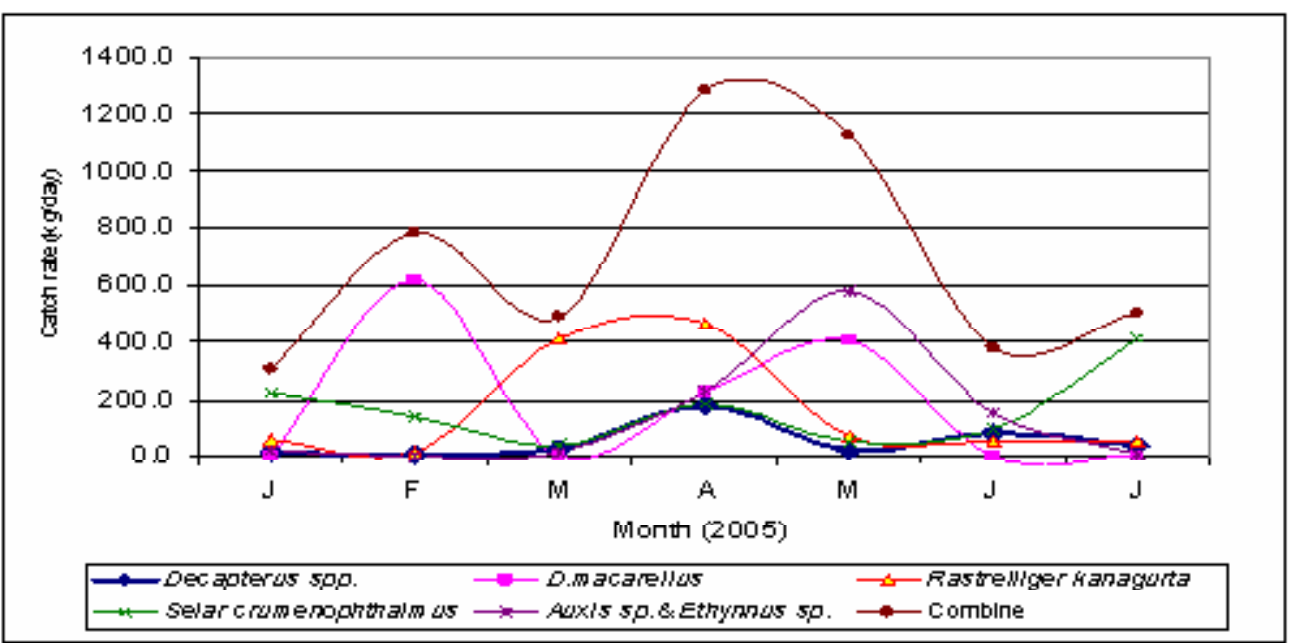

Gambar 5b. Laju tangkap 5 jenis ikan pelagis yang dominan oleh pukat rapat dari armada pukat cincin Sibolga dari bulan Januari sampai dengan Juli 2005.

Figure 5b. Catch rate of the 5 dominant pelagic fishes by pukat rapat of Sibolga purse seiner's fleet from January to July 2005.

Tabel 5. Laju tangkap pukat jarang Sibolga pada bulan Januari sampai Juli 2003 dan 2005 Table 5. $\quad$ Catch rate of pukat jarang at a period of January to July 2003 and 2005

\begin{tabular}{|c|c|c|c|c|}
\hline \multirow[t]{2}{*}{ No. } & \multirow[t]{2}{*}{$\begin{array}{l}\text { Spesies dan nama Indonesia/ } \\
\text { Species and Indonesian name }\end{array}$} & \multicolumn{2}{|c|}{$\begin{array}{c}\text { Laju tangkap/ } \\
\text { Catch rate (kg/day) } \\
\text { from January to July in } \\
\text { years }\end{array}$} & \multirow[t]{2}{*}{$\begin{array}{l}\text { Keterangan/ } \\
\text { Remark }\end{array}$} \\
\hline & & 2003 & 2005 & \\
\hline 1. & Katsuwonus pelamis(cakalang) & $1.059,3$ & $1.501,2$ & Naik/Increase \\
\hline 2. & Thunnus albacares (tuna) & 252,0 & 344,3 & Naik/Increase \\
\hline 3. & Auxis sp. dan Eutynnus sp. (tongkol) & 121,9 & 92,4 & Turun/Decrease \\
\hline \multirow[t]{2}{*}{4.} & Others(lain-lain) & 434,5 & 318,2 & Turun/Decrease \\
\hline & Total & $1.867,6$ & $2.256,1$ & Naik/Increase \\
\hline
\end{tabular}




\section{BAHASAN}

Jumlah kapal pukat cincin turun dari 203 unit pada tahun 2003 menjadi 198 unit pada tahun 2004 dan 152 unit pada tahun 2005, menyebabkan turunnya jumlah trip selama tahun 2004 dan 2005 dari tahun 2002 dan 2003. Tiap kapal membawa 2 jenis pukat, yaitu pukat rapat dan pukat jarang, masing-masing pukat dioperasikan pada trip yang berbeda.

Jumlah hari di laut pukat rapat dan pukat jarang pada periode bulan Januari sampai dengan Juli 2005 (sesudah Tsunami) turun dari jumlah hari di laut masing-masing pukat pada periode yang sama tahun 2003 (sebelum Tsunami). Beberapa kendala penyebab turunnya jumlah upaya pada tahun 2004 dan 2005 tersebut karena ada patroli pemeriksaan dan larangan beroperasi bagi kapal-kapal pukat cincin yang belum selesai mengurus perpanjangan izin, kerusakkan sarana pendaratan dan beberapa kapal akibat Tsunami dan kelangkaan dan kenaikan harga bahan bakar minyak. Dampak Tsunami terhadap jumlah upaya kapal pukat cincin terjadi pada bulan Januari dan Pebruari 2005.

Naik hasil tangkapan total dan turun jumlah hari di laut pukat rapat sesudah Tsunami dapat dijadikan indikasi bahwa sumber daya ikan khususnya pelagis kecil di daerah penangkapan pukat cincin Sibolga telah mengalami tekanan penangkapan.

Jenis-jenis hasil tangkapan pukat rapat yang terdiri atas kelompok ikan pelagis kecil, tongkol (pelagis besar), dan lain-lain, serta jenis jenis hasil tangkapan pukat jarang terutama kelompok ikan pelagis besar pada periode sesudah Tsunami sama dengan periode sebelum Tsunami. Tidak berkurang dan tidak bertambah.

Sesudah Tsunami, sebaran temporal (bulanan) hasil tangkapan pukat rapat dari jenis ikan pelagis yang dominan tertangkap dengan pukat rapat, yang terdiri atas 4 jenis ikan pelagis kecil yaitu ikan layang (Decapterus russelli dan D.macrosoma), layang biru (D. macarellus), bentong (Selar crumenophthalmus), dan banyar (Rastrelliger kanagurta) serta ikan tongkol (Auxis sp. dan Euthynnus sp.) kurang merata dan berfluktuasi tajam dibandingkan dengan sebelum Tsunami. Sebelum Tsunami, hampir pada tiap bulan ikan tongkol dan bentong paling tinggi, disusul oleh ikan layang, layang biru, serta banyar, sedangkan pada sesudah Tsunami, jenis-jenis ikan tersebut tidak selalu dapat tertangkap tiap bulan (bulan Januari sampai dengan Juli 2005). Penyebab lebih berfluktuasi hasil tangkapan pada beberapa bulan sesudah Tsunami belum diketahui dengan jelas.
Hasil tangkapan dan laju tangkap ke- 5 jenis ikan pelagis dominan pada sebelum Tsunami, yang tertinggi terjadi pada bulan Maret 2003, paling rendah pada bulan April 2003. Sesudah Tsunami, hasil tangkapan dan laju tangkap yang tertinggi pukat rapat terjadi pada bulan April dan Mei, terendah pada bulan Januari 2005, yang secara kebetulan paling dekat dengan terjadi Tsunami. Pergeseran waktu hasil tangkapan tertinggi sesudah Tsunami tersebut dari puncak hasil tangkapan sebelun Tsunami wajar karena dalam musim yang sama yaitu musim peralihan 1 (bulan Maret sampai dengan Mei).

Baik pada pukat rapat maupun pukat jarang, laju tangkap sesudah Tsunami meningkat, diduga disebabkan oleh jumlah hari di laut masing-masing pukat yang menurun.

\section{KESIMPULAN}

1. Penurunan aktivitas (jumlah kapal, trip, dan hari di laut) pada bulan Januari dan Pebruari 2005 terutama disebabkan oleh kerusakkan kapal-kapal dan tangkahan-tangkahan pukat cincin Sibolga akibat gelombang Tsunami yang terjadi pada akhir bulan Desember 2004.

2. Jenis-jenis ikan pelagis kecil, pelagis besar, dan ikan lain-lain yang tertangkap dengan pukat rapat dan pukat jarang sesudah Tsunami (bulan Januari sampai dengan Juli 2005) sama dengan sebelum Tsunami (bulan Januari sampai dengan Juli 2003).

3. Peningkatan laju tangkap total pukat rapat maupun pukat jarang sesudah Tsunami lebih disebabkan karena penurunan aktivitas (jumlah hari di laut).

\section{PERSANTUNAN}

Kegiatan dari hasil riset Penyerasian Sumber Daya Ikan, T.A. 2004-2005, di Pusat Riset Perikanan Tangkap-Ancol, Jakarta.

\section{DAFTAR PUSTAKA}

Hariati, T. 2001. Pemanfaatan ikan pelagis kecil oleh armada pukat cincin di perairan barat Sumatera. Dalam Pesisir dan Pantai Indonesia VI. Pusat Penelitian dan Pengembangan Oseanologi. Lembaga Ilmu Pengetahuan Indonesia. Hal.29-39.

Hariati, T. 2005. Perkembangan pemanfaatan ikan pelagis kecil menggunakan pukat cincin Sibolga di perairan barat Sumatera pada tahun 2003. Jurnal Penelitian Perikanan Laut. Vol.11 No.2. Hal.57-67. 
Herlisman. 2003. Karakteristik dan sirkulasi massa air serta kaitannya dengan kelimpahan fitoplankton di perairan laut barat daya Pulau NiasKepulauan Mentawai pada bulan Desember 1993 (musim barat). Thesis S2. Program Pasca Sarjana. Institut Pertanian Bogor. Jurusan IImu Kelautan. Unpublished. 80 hal.

Hirata, K. 2005. The 2004 Sumatera earthquake and Tsunami. Presented in the Workshop of Indonesian Earthquake and Indian Tsunami, $26^{\text {th }}$ December 2004. State Ministry of Research and Technology. Agency for Assessment and Application of Technology, and Japan Agency for Marine Earth Science and Technology. 17p.

Sadhotomo, B., Sulistijo, \& A. Djamali. 2005. Some notes on pelagic fishery data along south-western coast of Sumatera. Proceeding Seminar of West Sumatera on Post Tsunami Expedition 2005. Aceh and Western Sumatera Coast IIS-IMR Norway. p 86-90.

Sulistijo, B. Sadhotomo, A. Djamali, \& M. Taufiq. 2005. Pelagic fish catch composition of the eastern and western coast of Sumatera. Proceeding Seminar of West Sumatera on Post Tsunami Expedition 2005. Aceh and Western Sumatera Coast IIS-IMR Norway. p 130-142.

Wijopriono \& A. Priatna. 2005. Abundance and distribution of the small pelagic fishes using acoustic method. Proceeding Seminar of West Sumatera on Post Tsunami Expedition 2005. Aceh and Western Sumatera Coast IIS-IMR Norway. p 91-98. 